\title{
Irrigation Management Using Different Irrigation Scheduling Techniques in Blocked-end Furrows
}

\author{
Mohamed Khaled Salahou ${ }^{1,2}$, Xi-yun Jiao ${ }^{1,2}$, Kaihua Liu ${ }^{1,2}$ \\ ${ }^{1}$ State Key Laboratory of Hydrology -Water Resources and Hydraulic Engineering, College of Water \\ Conservancy and Hydropower Engineering, Hohai University, Nanjing 210098, China \\ ${ }^{2}$ College of Water Conservancy and Hydropower Engineering, Hohai University, Nanjing 210098, \\ China
}

salahou3@hotmail.com,xyjiao@hhu.edu.cn, 150402060005@hhu.edu.cn

Keywords: Furrow irrigation; Inflow variation; Infiltration parameters; Irrigation evaluation; Irrigation efficiency.

Abstract:Surface irrigation under different irrigation techniques is evaluated in this research, based on water applying method, water infiltration depth, and irrigation water use efficiency. For that purpose, field experiments were conducted using cotton grown in silt loam soil at Wuqiao Eco-Agricultural Experimental Station in 2015 season. To evaluate the infiltration and distribution under conventional continuous inflow in comparison to increased discharge and decreased discharge irrigation in blockedend furrows, nine irrigation treatments were applied. They are known as continuous flow irrigation (CFI), decreased discharge irrigation (DDI) and increased discharge irrigation (IDI). In DDI and IDI irrigation treatments, the inflow should be varied before the completion of the advance phase and cut off time in all treatments when the advance wave reaches the end of the field. The infiltration depth in $\mathrm{cm}$ was functioned to opportunity time $(\tau)$ in minute for the double ring infiltrometer as: $Z=0.51 \tau^{0.381}$.The average application efficiency of DDI irrigation is higher than that of CFI and IDI irrigation treatments. Decreased discharge in DDI irrigation treatment when the position of the advancing wave front reaches 0.75 of the furrow's length can potentially save water and irrigation time compared with other irrigation treatments.

\section{Introduction}

In recent years, several models have been developed for simulating the interactions between the height of the water above the furrow bed and soil water movement, these models are possible to estimate the Infiltration parameters based on different conditions (e.g. border irrigation, blocked-end and free draining furrows) and infiltration equations (e.g. Kostiakov, modified Kostiakov or SaintVenant equations) [1-10].

Several authors have discussed some irrigation practices to improve irrigation performance. For example, Amer and Amer [11] and Amer [12] discussed some works which conclude that application efficiency can be higher than $86 \%$ if furrow irrigation is practiced well under the short irrigation interval using furrow irrigation with little amount of water. Koech, et al. [13] developed Real-time prediction of time to cut off $\left(\mathrm{T}_{\mathrm{co}}\right)$ for furrow irrigation to modify and adopt the time to cut-off in order to expected the changes in soil moisture deficit, soil properties and inflow rate whilst the irrigation is still underway. Smith, et al. [14] reached that application efficiencies higher than 90\% achievable through the use of correct and accurate management of the automated irrigation.

A number of other irrigation management techniques have been developed that can be used to replace the traditional continuous inflow to reduce water losses and improve water uniformity and irrigation water use efficiency during the irrigation event. Some of these methods are as follows: (1) Surge irrigation [15-20], (2) decreased discharge method (Cutback method) is to reduce runoff losses through the commence of the irrigation with a high inflow rate that ensures rapid advance but that reduces the inflow when the water has reached the end of the field $[4,21,22]$. The advantage of this technique may 
be greater since the maximum inflow rate was limited by the recommended erosion limits. Perhaps an inherent limitation of the decreased discharge irrigation is, that it is very sensitive to the field parameters and care is required to ensure that the reduced inflow rate is sufficient to prevent tail end recession, and (3) increased discharge method (inverses cutback) is a technique where the inflow is applied to the furrows until the advance reaches the end of the field. At this point, the flow is increased [23]. The primary advantage of this technique is the reduction in soil erosion from the upper reaches and accurate the advance phase relative to decreased discharge and continuous flow irrigations. Vázquez-Fernández [24] proposed that the inflow should be increased earlier, when the advance has reached $1 / 4$ of the field. The increased discharge technique has performed favorably on blocked-end furrows.

Although study conducted in Mexico [23] under bare conditions have indicated that increased discharge irrigation improves irrigation performance comparing with continuous flow irrigation, it is imperative to test its validity under different flow, soil and crop conditions. The objective of this study is to compare between increased discharge, decreased discharge and continuous flow irrigations in block-end furrows for cotton crop in 2015 season to estimate the possibilities of improving furrow irrigation performances. This study proposed that the inflow in the decreased discharge irrigation (DDI) and increased discharge irrigation (IDI) treatments should be varied before the completion of the advance phase and cut off time in all treatments when the advance wave reaches the end of the field. The purpose of such comparison was to confirm the best alternative method to the other.

\section{Materials and methods}

\section{Study area}

Irrigation evaluations were performed in a cotton field located at Wuqiao Eco-Agricultural Experimental Station, situated to the south of the city of Cangzhou ( around $45 \mathrm{~km}$ ), Hebei Province, China with geographic coordinates: Latitude $37^{\circ} 65^{\prime}$ and Longitude $116^{\circ} 37^{\prime}$ and an average elevation above sea level to $16 \mathrm{~m}$. The climate is characterized as semi-humid continental, where average annual evaporation range between $1500-1800 \mathrm{~mm}$, with summer rains, average annual precipitation is 576 $\mathrm{mm}$ and average annual temperature is $12.6^{\circ} \mathrm{C}$.

\section{Soils}

The soil of the studied area is silt loam in texture (61.9\% silt, $28.3 \%$ sand, and $9.8 \%$ clay on average), the physical properties of the soil in the study was determined according to [25]. As shown in Table 1. The bulk density increased from $1.44 \mathrm{~g} / \mathrm{cm}^{3}$ in the soil surface $(0-10 \mathrm{~cm})$ to $1.46 \mathrm{~g} / \mathrm{cm}^{3}$ in deeply subsurface $(20-30 \mathrm{~cm})$, but it decreased in the lower depths with an average $1.41 \mathrm{~g} / \mathrm{cm}^{3}$ for $0.5 \mathrm{~m}$ soil depth.

Table 1. Variation of soil bulk density with soil depth

\begin{tabular}{ccc}
\hline No & Soil depth $(\mathrm{cm})$ & $\begin{array}{c}\text { Bulk density } \\
\left(\mathrm{g} / \mathrm{cm}^{3}\right)\end{array}$ \\
\hline 1 & $0-10$ & 1.44 \\
2 & $10-20$ & 1.47 \\
3 & $20-30$ & 1.46 \\
4 & $30-40$ & 1.37 \\
5 & $40-50$ & 1.41 \\
\hline Average & & 1.43 \\
\hline
\end{tabular}

\section{Inflow rates}

Inflows delivered to the furrow were measured at each furrow with flow meters and only one furrow was irrigated at a time and the full inflow through the service point was applied to the that furrow. An averaged initial and later inflow rate were used in all of the evaluations. 


\section{Soil moisture}

Soil profile moisture was measured throughout the irrigation season with drying a soil to constant weigh. Samples were taken in the centerline of each furrow at 20, 113 and $220 \mathrm{~m}$ from the furrow's header. Readings were taken at $0.2 \mathrm{~m}$ intervals down the soil profile to a depth of $0.6 \mathrm{~m}$ at approximately two to five days before and one to three days after each irrigation. Additional samples were taken between the second and the third irrigation at 20 and $113 \mathrm{~m}$ of the furrow length.

\section{Experimental treatments}

Irrigation furrow treatments were increased and decreased discharge irrigation compared to continuous flow irrigation. Test furrows have the following characteristics: V-shaped, $0.3 \mathrm{~m}$ top width, 0.2 maximum height, $235 \mathrm{~m}$ length, $0.6 \mathrm{~m}$ furrow space, and $0.09 \%$ slope. The water cut-off in all furrow treatments after the completion of advance phase. The water infiltration depth of soil was obtained with the Kostiakov equation (1932) [26] where the parameters of the Kostiakov equation (1932) were obtained with the double ring infiltrometer. The furrow irrigation system was developed to supply water into cotton field using pipelines thus reducing the wetted surface area in order to save water. Advance and recession times were measured in each evaluated furrow at each $5 \mathrm{~m}$ (furrow tail) from the head.

\section{Water uniformity and irrigation water use efficiency}

In design and management of irrigation systems, efficient use of water is now often a major goal, as well as production of the crop [27]. Evaluation of furrow irrigation system performance is calculated using the following indicators. Distribution uniformity DU defined as the ratio of the average depth infiltrated in the quarter of the field with the lowest infiltrated depths $\overline{Z_{L Q}}$ to the average infiltrated depth $\bar{Z}[27]$ that is,

$D U=\frac{\overline{Z_{L Q}}}{\bar{Z}}$

A second evaluation is also presented with application efficiency $\left(E_{a}\right)$ with no tail water runoff, defined as the ratio of infiltrated water stored in the root zone to the total water applied, application efficiency $\left(\mathrm{E}_{\mathrm{a}}\right)$ was evaluated considering the methodology proposed by Amer [12]

$$
\begin{aligned}
& E_{a}=1+\alpha C V \\
& \alpha=\frac{1}{C V}\left(\frac{d}{\bar{Z}}-1\right) \\
& C V=0.3\left(\frac{Z_{\text {max }}-Z_{\text {min }}}{\bar{Z}}\right)
\end{aligned}
$$

In which $\mathrm{d}=$ irrigation water depth expressing the plant water requirement; $\mathrm{CV}=$ coefficient of variation; $\alpha=$ schedule parameter; $\mathrm{Z}_{\max }$ and $\mathrm{Z}_{\min }=$ the maximum and minimum infiltration depths.

\section{Results and discussion}

\section{Soil infiltration function}

Infiltration rates (Fig. 1) was measured using a double-ring infiltrometer. Repeated readings were taken at 2-10 minutes intervals at three different locations. The average points in the figure were taken from the measured values (different locations) at regular time intervals, the difference between duplicate curves at a given time showed at each point. The accurate of the method for estimating infiltration function was excellent considering the average relative error between measurements. 


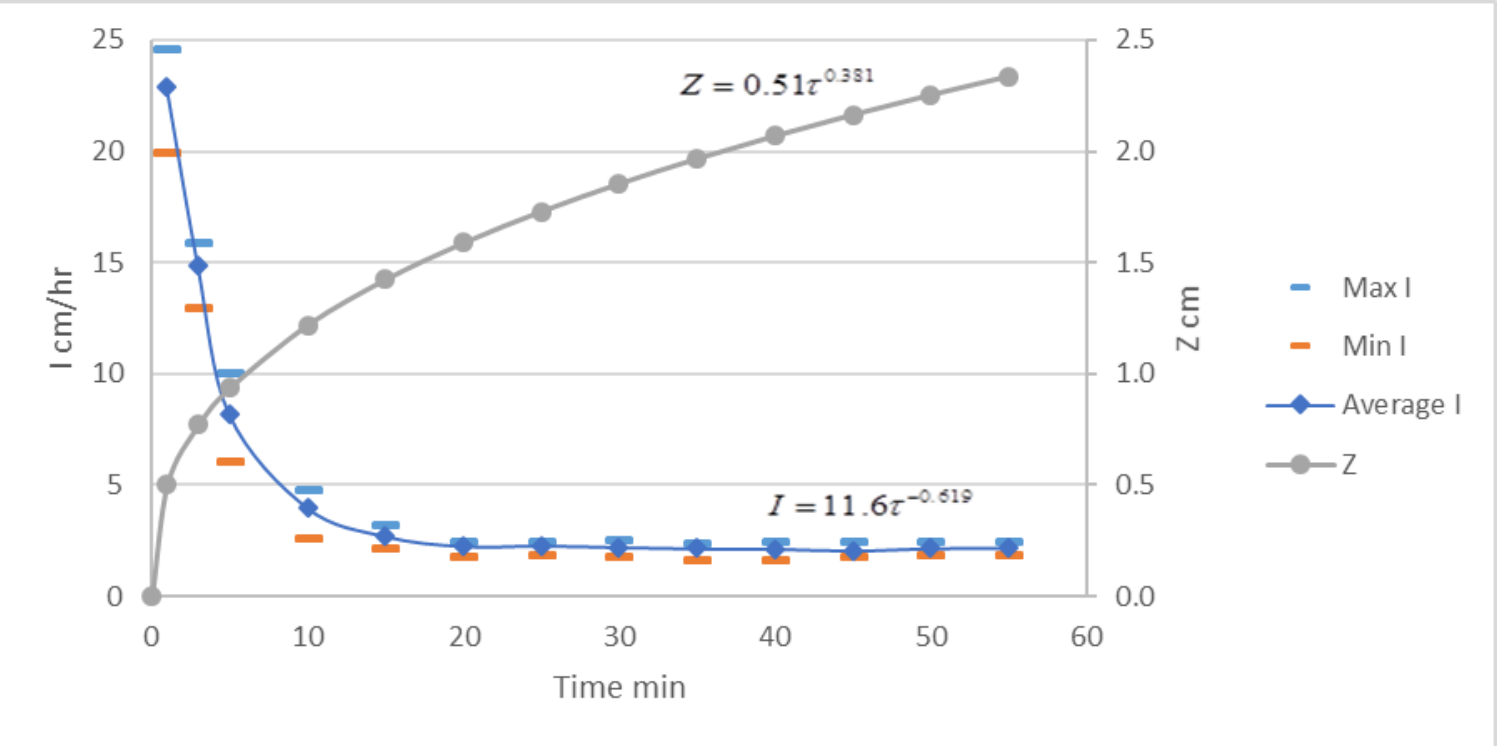

Fig. 1. Field infiltration rate, I (cm/h) and cumulated infiltrated depth $\mathrm{Z}(\mathrm{cm})$

Infiltration rate (I in $\mathrm{cm} / \mathrm{h}$ ) as fitted to Kostiakov equation (1932) [26] was $I=11.6 \tau^{-0.619}$ and the average minimum value of $2.2 \mathrm{~cm} / \mathrm{h}$ infiltration rate found for the treatments and considered as the basic infiltration rate. Cumulative infiltrated depth $\mathrm{Z}$ in $\mathrm{cm}$ was integrated from infiltration rate function and reported as $Z=0.51 \tau^{0.381}$, where $Z$ in $\mathrm{cm}$ and $\tau$ in minute.

\section{Water application by furrow irrigation}

Table 2 presents initial inflow rates, later inflow rates, increased/decreased discharge time and fraction of furrow length for which the varied-discharge rate was performed for different irrigations, where CFI, DDI and IDI correspond to continuous flow irrigation, decreased-discharge irrigation and increaseddischarge irrigation respectively.

Table 2. Flow Rate, Time, and cumulative volume release of Irrigations

\begin{tabular}{|c|c|c|c|c|c|c|}
\hline $\begin{array}{c}\text { Irrigation } \\
\text { Type }\end{array}$ & $\begin{array}{c}\text { Irrigation } \\
\text { Event }\end{array}$ & $\begin{array}{c}\text { Initial } \\
\text { inflow rate } \\
\mathrm{Q}_{1}(\mathrm{~L} / \mathrm{s})\end{array}$ & $\begin{array}{c}\text { Later } \\
\text { inflow rate } \\
\mathrm{Q}_{2}(\mathrm{~L} / \mathrm{s})\end{array}$ & $\mathrm{L}_{\mathrm{i}}^{*}$ & $\begin{array}{c}\mathrm{T}_{\mathrm{co}}=\mathrm{T}_{\mathrm{a}}=\mathrm{T}_{\mathrm{r}}{ }^{*} \\
(\mathrm{~min})\end{array}$ & $\begin{array}{c}\mathrm{T}_{\mathrm{i}} * \\
(\mathrm{~min})\end{array}$ \\
\hline CFI & 2 & 1.14 & 1.14 & - & 115.4 & - \\
\hline IDI (1) & 1 & 1.0 & 2.0 & 0.90 & 132.0 & 115.0 \\
\hline IDI (2) & 1 & 0.9 & 1.8 & 0.75 & 131.0 & 100.0 \\
\hline IDI (3) & 3 & 0.8 & 1.6 & 0.50 & 116.2 & 65.0 \\
\hline IDI (4) & 3 & 0.8 & 1.6 & 0.25 & 93.1 & 25.0 \\
\hline DDI (1) & 1 & 2.0 & 1.0 & 0.90 & 66.0 & 57.0 \\
\hline DDI (2) & 1 & 1.8 & 0.9 & 0.75 & 78.0 & 50.0 \\
\hline DDI (3) & 3 & 2.0 & 1.0 & 0.50 & 106.0 & 26.0 \\
\hline DDI (4) & 3 & 2.0 & 1.0 & 0.25 & 119.00 & 10.0 \\
\hline
\end{tabular}

* $\mathrm{L}_{\mathrm{i}}=$ Fraction of furrow length at the increment/ decrement inflow

$\mathrm{T}_{\mathrm{co}}=$ Cutoff Time, $\mathrm{T}_{\mathrm{a}}=$ Total advance Time, $\mathrm{T}_{\mathrm{r}=}$ Irrigation Time

$\mathrm{T}_{\mathrm{i}}=$ Time of flow rate increment $/$ decrement

Fig. 2 shows the differences in advance rates resulting from differences in the initial and later inflow rates. The advance phase of the DDI (1) and DDI (2) are very fast compared with other irrigation types, because the initial inflow was high and the later low inflow was performed when the advance phases 
reached 0.9 and 0.75 of the furrow length, respectively. Fig. 2 also shows that the combination of initial high flow rate and later low flow rate can decrease the advance time. Therefore, this combination increases the opportunity time in the lower quarter of the field. The advance phase time in all treatments ranged between $66 \mathrm{~min}$ and $131 \mathrm{~min}$.

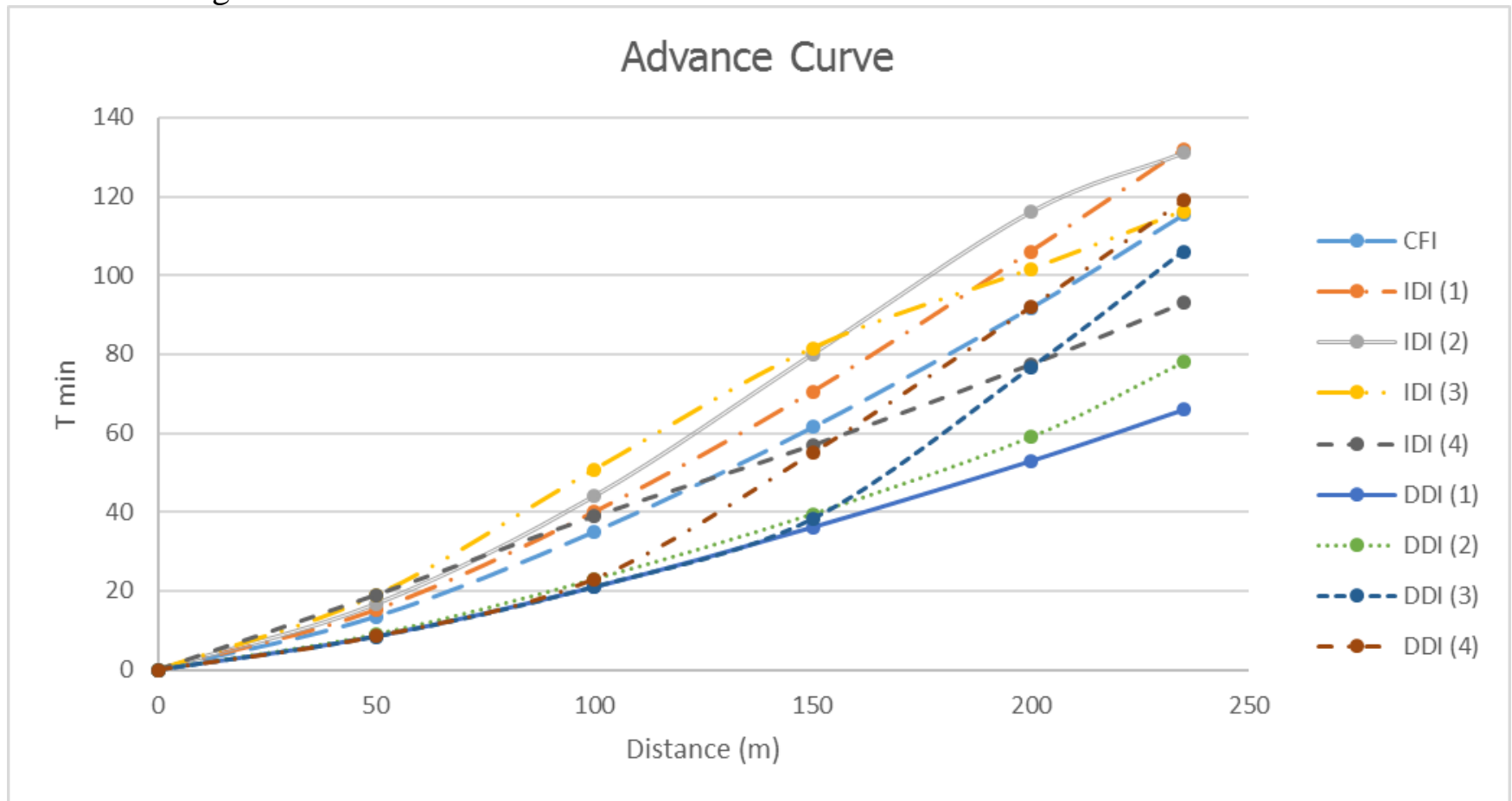

Fig. 2. Water advance trajectories

Table 3 shows the infiltration water depth and the average infiltration depth along the furrow for different irrigation techniques where the cumulative depth of infiltration $\mathrm{Z}(\mathrm{mm})$ is calculated by the previous Kostiakov equation (where the opportunity time is the difference between the measurement advance and recession time). The difference between average infiltration depth and the infiltration depths along the furrows (DU, $\mathrm{E}_{\mathrm{a}}$ ) described in the following sections.

Table 3. Infiltrated water depths (mm)

\begin{tabular}{|c|c|c|c|c|c|c|c|}
\hline \multirow{2}{*}{$\begin{array}{c}\text { Irrigation } \\
\text { Type }\end{array}$} & \multicolumn{6}{|c|}{ Distance in the furrow $(\mathrm{m})$} & \multirow{2}{*}{ Average } \\
\hline & 0.0 & 50.0 & 100.0 & 150.0 & 200.0 & 235.0 & \\
\hline CFI & 33.3 & 33.1 & 32.6 & 34.3 & 34.6 & 33.9 & 33.6 \\
\hline IDI (1) & 35.2 & 35.3 & 38.5 & 41.2 & 41.4 & 40.5 & 38.7 \\
\hline IDI (2) & 35.1 & 35.1 & 37.7 & 39.3 & 39.7 & 39.6 & 37.7 \\
\hline IDI (3) & 33.7 & 33.0 & 33.5 & 35.2 & 36.8 & 36.7 & 34.8 \\
\hline IDI (4) & 31.3 & 30.4 & 32.1 & 35.7 & 36.6 & 36.3 & 33.7 \\
\hline DD1 (1) & 28.0 & 28.1 & 29.7 & 32.8 & 34.4 & 34.3 & 31.2 \\
\hline DD1 (2) & 29.1 & 29.2 & 28.5 & 29.3 & 29.7 & 28.6 & 29.1 \\
\hline DD1 (3) & 32.3 & 32.5 & 32.3 & 34.4 & 33.9 & 32.2 & 32.9 \\
\hline DD1 (4) & 33.5 & 33.8 & 36.8 & 36.8 & 33.8 & 32.4 & 34.5 \\
\hline
\end{tabular}




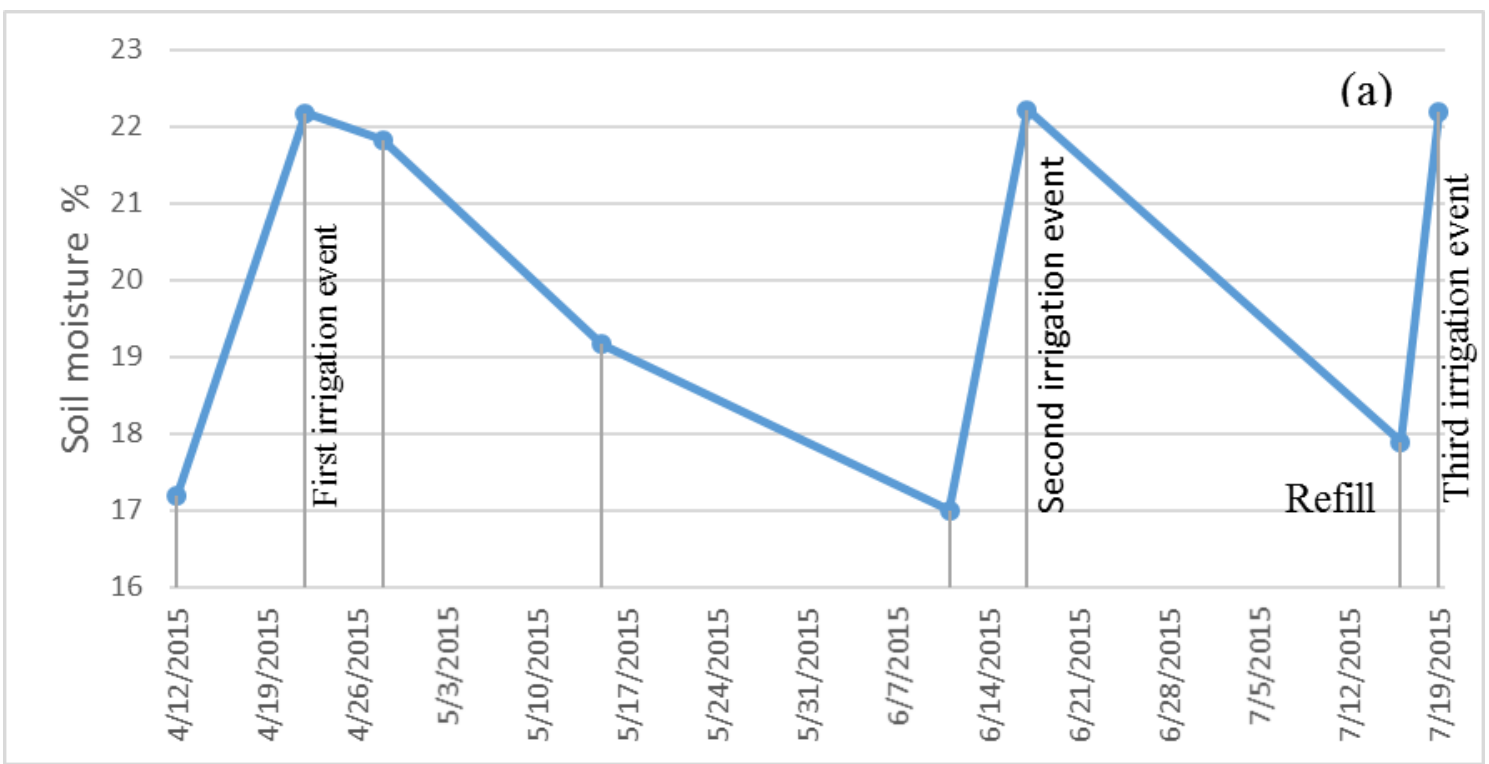

Fig. 3. Soil moisture measurement in time throughout the irrigation season

Consistent irrigations were applied at the experimental field, irrigations commencing at approximately 17\% moisture contents (see moisture content plot in Fig.3).

\section{Irrigation performances and scope for improvement}

Table 4 presents the results of irrigation effecienies and field observations for CFI, DDI and IDI irrigation treatments. According to this information, in general the DDI irrigation duration was short compare with CFI and IDI irrigations, The distribution uniformity and application efficiency were estimated for CFI irrigation treatment, the values were $100 \%$ and $96.9 \%$ respectively, the irrigation time was $115.4 \mathrm{~min}$ and the cumulative water release was $7.89 \mathrm{~m}^{3}$. In the IDI irrigation treatments the flow increase was performed when the water reached $0.9,0.75,0.5$ and 0.25 of the furrow's length, obtained DU $=100 \%$ and irrigation application efficiencies obtained averaged $92 \%$ (range $90-94 \%$ ) with the highest application efficiency when the inflow increase was performed at 0.5 of the furrow's length. The cumulative water release was the highest in the IDI irrigation treatments. In the DDI irrigation treatments the flow decrease was also performed at $0.9,0.75,0.5$ and 0.25 of the furrow's length. DU was $97.5 \%$ and irrigation application efficiencies averaged $94.7 \%$ (range $89-97 \%$ ) with the highest application efficiency and distribution uniformity when the inflow decrease was performed at 0.5 and 0.75 of the furrow's length. DDI irrigation saves water and irrigation time compared with CFI and IDI irrigation treatments. The DDI irrigation strategy inevitably results in water amount rapidly reaches to the low quarter and hence increased infiltration opportunity in the lower quarter and increased therefore application efficiency and distribution uniformity. The DDI (2) irrigation duration was appropriate to the prescribed inflow rates and that conferred high efficiencies, the distribution uniformity (DU) and application efficiency were $98.6 \%$ and $97.7 \%$, respectively. There is therefore an evidence to encourage the DDI irrigation method when the water reaches 0.75 of the furrow's length. According to these and previous results, DDI irrigation method is recommended to be used to establish good irrigation practices.

The crop growth stage is the critical factor in determining the initial and the later inflow rate to be used, this meant that the optimum irrigation initial and later inflow varied from one irrigation to the next according to the crop root depth or requirement infiltration depth. The inflow strategy used in this study is where the irrigation is shut off at the end of the field. In this case, selection of the initial and later inflow rate depends entirely on having right strategy and calculating the correct duration for initial and later inflow rates. For example, the DDI (2) irrigation treatment, the initial flow rate was $1.81 / \mathrm{sec}$, the later flow rate was $0.9 \mathrm{l} / \mathrm{sec}$, and the $\mathrm{T}_{\mathrm{co}}=\mathrm{T}_{\mathrm{r}}$ is $78 \mathrm{~min}$; hence, a volume of $6.78 \mathrm{~m}^{3}$ of water is applied. 
At these specified flow rates, the average infiltration depth was $29.1 \mathrm{~mm}$. Using flow rates higher than those used in DDI (2) irrigation treatment, the average infiltration depth would have been increased from the measured value $29.1 \mathrm{~mm}$ and arguably is a suitable strategy when crop is in a mid-season. Consequently, this approach is adaptive. It is also very easy to managed, when the irrigation advance reaches at the end field, the irrigation is shut off. An instruction close the furrow end can be installed to record the rate of advance of the irrigation flow down the furrow and the flow depth. The irrigated area received only surplus of water along the furrow lengths, therefore, the irrigated area did not have any water deficit and storage efficiency was $100 \%$ for all treatments.

Table 4. Irrigation system evaluation

\begin{tabular}{|c|c|c|c|c|c|c|c|c|c|}
\hline \multirow{4}{*}{$\begin{array}{l}\text { Parameters } \\
\text { Treatment }\end{array}$} & \multicolumn{9}{|c|}{ Furrow Irrigation } \\
\hline & \multicolumn{9}{|c|}{$\mathrm{Tco}=\mathrm{Ta}$} \\
\hline & \multirow{2}{*}{$\begin{array}{c}\begin{array}{c}\text { Conti } \\
\text { nuous } \\
\text { flow }\end{array} \\
\text { CFI }\end{array}$} & \multicolumn{4}{|c|}{ Increased inflow treatments } & \multicolumn{4}{|c|}{$\begin{array}{l}\text { Decreased inflow } \\
\text { treatments }\end{array}$} \\
\hline & & $\begin{array}{l}\text { IDI } \\
(1)\end{array}$ & $\begin{array}{l}\text { IDI } \\
(2)\end{array}$ & $\begin{array}{l}\text { IDI } \\
(3)\end{array}$ & $\begin{array}{l}\text { IDI } \\
(4)\end{array}$ & $\begin{array}{l}\text { DD1 } \\
(1)\end{array}$ & $\begin{array}{l}\text { DD1 } \\
(2)\end{array}$ & $\begin{array}{c}\text { DD1 } \\
\text { (3) }\end{array}$ & $\begin{array}{c}\text { DD1 } \\
\text { (4) }\end{array}$ \\
\hline $\begin{array}{l}\text { Cumulative } \\
\text { release (m3) }\end{array}$ & 7.89 & 9.09 & 8.88 & 8.16 & 7.86 & 7.23 & 6.78 & 7.74 & 7.89 \\
\hline $\begin{array}{l}\text { Toff }=\mathrm{Ta}=\mathrm{Tr} \\
(\mathrm{min})\end{array}$ & 115.4 & 132 & 131 & 116.2 & 93.1 & 66 & 78 & 106 & 119 \\
\hline $\begin{array}{l}\text { Distribution } \\
\text { uniformity } \\
\text { (DU) (\%) }\end{array}$ & 100 & 100 & 100 & 100 & 100 & 100 & 98.6 & 97.8 & 93.9 \\
\hline $\begin{array}{l}\text { Coefficient of } \\
\text { variation } \\
\text { (CV)\% }\end{array}$ & 1.84 & 4.76 & 3.71 & 3.29 & 5.48 & 6.18 & 1.23 & 1.97 & 3.85 \\
\hline $\begin{array}{c}\text { Schedule } \\
\text { parameter }(\alpha)\end{array}$ & -1.70 & -1.86 & -1.90 & -1.60 & -1.80 & -1.67 & -1.65 & -1.11 & -1.59 \\
\hline $\begin{array}{l}\text { Application } \\
\text { efficiency (Ea) } \\
(\%)\end{array}$ & 96.90 & 91.10 & 92.9 & 94.70 & 90.1 & 89.6 & 97.7 & 97.8 & 93.9 \\
\hline
\end{tabular}

\section{Summary and Conclusion}

The main goal of this work was to compare water irrigation efficiencies between continuous flow irrigation, decreased discharge irrigation and increased discharge irrigation in blocked-end furrows. For that purpose, field evaluation experiments were carried out in cotton field from the $15^{\text {th }}$ of April 2015 to the $20^{\text {th }}$ of September 2015 season to estimate the possibilities of improving furrow irrigation performances under conditions of north China plain. The field is a silt loam soil, irrigated using dry furrow irrigation with blocked-end $235 \mathrm{~m}$ long and 0.09\% slope. IDI irrigation and DDI irrigation were applied based on inflow variation regime when the advance has reached $0.9,0.75,0.5$ and 0.25 of the field length. All treatments were applied based on water cut off when the position of the advancing wave front reaches the lower boundary. The results from the evaluations demonstrated higher efficiencies for the DDI irrigation method than the CFI and IDI irrigation method, because of achieving high efficiencies. It was also found that DDI irrigation method, when the position of the advancing wave front reaches 0.75 of the furrow's length, saved more water and time than the other irrigation treatments. Therefore, a certain amount of water that otherwise would have been lost as deep percolation was saved. That is a convenient management in the periods of short supply of water. 
It is recommendable that other evaluations with different characteristics of discharge techniques should be done, such as surge flow or decreased discharge irrigation that reduce the inflow rate when the advance of the slowest advancing furrow reaches the end of the field and inflow is stopped when the requirement efficiency reaches $100 \%$.

\section{Acknowledgments}

This work was financially supported by the National Natural Science Foundation of China (50979025).

\section{References}

[1] Strelkoff, T.S.; Clemmens, A.J.; El-Ansary, M.; Awad, M. Surface-irrigation evaluationmodels: Application to level basins in egypt. Soil \& Water Division of ASAE 1999, 42, 1027-1036.

[2] Holzapfel, E.A.; Jara, J.; Zuñiga, C.; Mariño, M.A.; Paredes, J.; Billib, M. Infiltration parameters for furrow irrigation. Agricultural Water Management 2004, 68, 19-32.

[3] Wöhling, T.h.; Schmitz, G.H.; Mailhol, J.C. Modeling two-dimensional infiltration from irrigation furrows. J. Irrig. Drain. Eng., 2004, 130, 296-303.

[4] Mateos, L.; Oyonarte, N.A. A spreadsheet model to evaluate sloping furrow irrigation accounting for infiltration variability. Agricultural Water Management 2005, 76, 62-75.

[5] Bautista, E.; Clemmens, A.J.; Strelkoff, T.S.; Niblack, M. Analysis of surface irrigation systems with winsrfr — example application. Agricultural Water Management 2009, 96, 1162-1169.

[6] Bautista, E.; Clemmens, A.J.; Strelkoff, T.S.; Schlegel, J. Modern analysis of surface irrigation systems with winsrfr. Agricultural Water Management 2009, 96, 1146-1154.

[7] Mailapalli, D.R.; Raghuwanshi, N.S.; Singh, R. Physically based model for simulating flow in furrow irrigation. I: Model development. J Irrig Drain E-Asce 2010.

[8] Etedali, H.R.; Ebrahimian, H.; Abbasi, F.; Liaghat, A. Evaluating models for the estimation of furrow irrigation infiltration and roughness. Spanish Journal of Agricultural Research 2011, 9 , 641-649.

[9] Moravejalahkami, B.; Mostafazadeh-Fard, B.; Heidarpour, M.; Abbasi, F. Comparison of multilevel calibration and volume balance method for estimating furrow infiltration. Journal of Irrigation and Drainage Engineering 2012, 138, 777-781.

[10] Salahou, M.K.; Jiao, X.y. Infiltration estimation: Past and future. 2015 International conference on materials Engineering and industrial applications 2015, 242-248.

[11] Amer, A.M.; Amer, K.H. Surface irrigation management in relation to water infiltration and distribution in soils. Soil \& Water Res. 2010, 3, 75-87.

[12] Amer, A.M. Effects of water infiltration and storage in cultivated soil on surface irrigation. Agricultural Water Management 2011, 98, 815-822.

[13] Koech, R.K.; Smith, R.J.; Gillies, M.H. A real-time optimisation system for automation of furrow irrigation. Irrigation Science 2014, 32, 319-327.

[14] Smith, R.J.; Uddin, J.M.; Gillies, M.H.; Moller, P.; Clurey, K. Evaluating the performance of automated bay irrigation. Irrigation Science 2016, 34, 175-185.

[15] Walker, W.R.; Skogerboe, G.V. Surface irrigation: Theory and practice. Surge flow surface irrigation. Surface Irrigation:Theory and Practice, Prentice-Hall, Englewood Cliffs, NJ (Chapter 9) 1987.

[16] Evans, R.G.; Girgin, B.N.; Chenoweth, J.F.; Kroeger, M.W. Surge irrigation with residues to reduce soil erosion Agricultural Water Management 1995, 27, 283-297

[17] El-dine, T.G.; Hosny, M.M. Field evaluation of surge and continuous flows in furrow irrigation systems. Water Resources Management 2000, 14, 77-87. 
[18] Wang, W.-Y.; Luo, W.; Wang, Z.-R. Surge flow irrigation with sediment-laden water in northwestern china. Agricultural Water Management 2005, 75, 1-9.

[19] Horst, M.G.; Shamutalov, S.S.; Gonçalves, J.M.; Pereira, L.S. Assessing impacts of surge-flow irrigation on water saving and productivity of cotton. Agricultural Water Management 2007, 87, 115-127.

[20] Kifle, M.; Tilahun, K.; Yazew, E. Evaluation of surge flow furrow irrigation for onion production in a semiarid region of ethiopia. Irrigation Science 2007, 26, 325-333.

[21] Izadi, B.; Studer, D.; McCann, I. Maximizing set-wide furrow irrigation application efficiency under full irrigation strategy. Transactions of the ASAE 1991, 34, 2006-2014.

[22] Alazba, A.A. Dimensionless advance curve for infiltration families. Agricultural Water Management 1999, 41, 115 \pm 131 .

[23] Vázquez-Fernández, E.; López-Tellez, P.; Chagoya-Amador, B. Comparison of water distribution uniformities between increased-discharge and continuous-flow irrigations in blocked-end furrows. J. Irrig. Drain. Eng., 2005, 131, 379-382.

[24] Vázquez-Fernández, E. Comparison between continuous-flow and increased-discharge irrigations in blocked-end furrows using a mathematical model Applied engineering in agriculture 2006, 22, 375-380.

[25] Klute, A. Method of soil analysis. Part i physical and mineralogical methods. 2nd ed. Soc. Agron. Inc. Pub., Madison Wisconsin, USA 1986.

[26] Kostiakov, A.N. On the dynamics of the coefficient of water percolation in soils and on the necessity for studying it from a dynamic point of view for purposes of amelioration. Trans. 6th Comm. Int. Soc Soil Sci. Part A 1932, 17-21.

[27] Burt, C.M.; Clemmens, A.J.; Strelkoff, T.S.; Solomon, K.H.; Bliesner, R.D.; Hardy, L.A.; Howell, T.A.; Eisenhauer, D.E. Irrigation performance measures: Efficiency and uniformity. J. Irrig. Drain. Eng., 1997, 123, 431. 